Research Article

\title{
Characteristics of Maternal Mortality Cases in a Tertiary Hospital
}

\section{Kajian Karakteristik Kematian Ibu di Rumah Sakit Tersier}

\author{
Junita Indarti, Ferry Y Irawan \\ Department of Obstetrics and Gynecology \\ Faculty of Medicinie Universitas Indonesia/ \\ Dr. Cipto Mangunkusumo Hospital \\ Jakarta
}

\begin{abstract}
Objective: To identify the characteristics of maternal mortality cases in a tertiary hospital in Jakarta, including socio-demographic characteristics, previous medical and obstetric history, and patient's clinical condition on arrival at the hospital.

Method: This was a survey to identify the descriptive data of maternal mortality cases through medical records during study period. Manual review of 51 medical records was conducted for 2 years from January 2013 to December 2014 in Department of Obstetrics and Gynecology, Dr. Cipto Mangunkusumo Hospital (RSCM).

Result: Of 51 cases of maternal deaths, 46 subjects $(90.19 \%)$ had nine years of minimum education background. There were two subjects less than 21 years old and another was 42 years old. None of these subjects were using intrauterine device (IUD) or implant as the contraceptive methods where $66.6 \%$ subjects with underlying disease never used contraception. Ninety-two percent of subjects did antenatal care (ANC) regularly and $80.4 \%$ (41 subjects) of them was done in midwives. There were 14 subjects $(29.78 \%)$ who had ANC in the first trimester of pregnancy. Severe preeclampsia is the most prevalent complication in pregnancy ( 26 subjects, $65 \%$ ), which all $(100 \%)$ patients arrived at RSCM with HELLP Syndrome. Therefore, preeclampsia was the leading cause of death in RSCM.

Conclusion: The characteristics of maternal death in RSCM are prevalent in the group of 25-34 years old with the high school as the educational background. Most of them are multiparity and do not use the long-term contraceptive methods. Preeclampsia is the major cause of maternal death in RSCM.
\end{abstract}

[Indones J Obstet Gynecol 2016; 4-3: 119-122]

Keywords: maternal mortality, risk factors, tertiary hospital

\section{Abstrak}

Tujuan: Mengidentifikasi karakteristik kematian ibu di RS tersier di Jakarta yang meliputi karakteristik sosio-demografi, riwayat obstetri dan medis, serta kondisi klinis pasien saat tiba di rumah sakit

Metode: Penelitian ini merupakan survei untuk mengetahui data deskriptif kematian maternal menggunakan rekam medis selama rentang waktu penelitian. Dilakukan telaah rekam medis 51 kasus kematian ibu yang terjadi selama 2 tahun dari Januari 2013 hingga Desember 2014 di bagian Obstetri dan Ginekologi, RSCM.

Hasil: Dari 51 kasus kematian maternal, 46 subjek $(90,19 \%)$ berpendidikan minimal sembilan tahun. Terdapat dua subjek yang berusia kurang dari 21 tahun dan satu subjek yang berusia 42 tahun. Tidak ada satupun subjek yang pernah menggunakan metode kontrasepsi IUD atau implan dengan 66,6\% subjek yang memiliki penyakit penyerta tidak pernah menggunakan kontrasepsi. Empat puluh tujuh subjek melakukan ANC yang umumnya dilakukan di bidan (41 subjek, 80,4\%) dan hanya 14 subjek $(29,78 \%)$ yang pernah menjalani ANC pada trimester pertama kehamilan. Preeklamsia berat merupakan komplikasi kehamilan yang paling banyak dijumpai (26 subjek, $65 \%$ ), di mana seluruhnya (100\%) tiba di RSCM dengan sindrom HELLP. Komplikasi preeklamsia adalah penyebab kematian utama.

Kesimpulan: Karakteristik kematian maternal di RSCM banyak terjadi pada usia 25-34 tahun dengan latar belakang pendidikan lulus SMA. Kebanyakan dari mereka multiparitas dan tidak menggunakan metode kontrasepsi jangka panjang. Preeklamsia merupakan penyebab kematian maternal di RSCM.

[Maj Obstet Ginekol Indones 2016; 4-3: 119-122]

Kata kunci: faktor risiko, kematian ibu, rumah sakit tersier

Correspondence: Ferry Y Irawan. Telephone: 0812-91415320, Email: fyama78@gmail.com

\section{INTRODUCTION}

Maternal deaths according to the Tenth Revision of the International Classification of Diseases (ICD10 ) is the death of a woman during pregnancy until 42 days after delivery, irrespective of the length and location of the pregnancy. Apart from that, it can be caused by anything related to pregnancy or aggravated by the pregnancy; it is not due to an accident, yet.1,2

Reducing maternal mortality has long been a priority on global health program and it is one of the targets in the United Nations Millennium Development Goals (MDGs) number five. Based on the Household Health Survey, maternal mortality rate (MMR) in Indonesia in 2001 was 396 per 100,000 live births; meanwhile, Indonesia Demographic and Health Survey (IDHS) 2002/2003 stated that the MMR was 307 per 100,000 live births. ${ }^{3}$ Actually, this was contrary to the MDGs target in 2015 namely 108 per 100,000 live births. ${ }^{4}$

In 2012, the number of maternal deaths in Jakarta were 97 patients. The highest incidence of MMR was located in East Jakarta (34), followed by 
North Jakarta (23). The main causes of maternal death in Jakarta in 2012 were preeclampsia/ eclampsia (39\%), bleeding (31\%), infection (6\%), abortion (2\%), prolonged labor (1\%) and others. Health status, education, accessibility to the health care, and services by health professionals during pregnancy and delivery influence the MMR. ${ }^{5}$

Dr. Cipto Mangunkusumo Hospital (RSCM) as a national referral center in Indonesia is the center of excellence consisting of education, research, and service for co-assistant, residents, nurses, and other health workers. ${ }^{6}$ As the tertiary hospital in Indonesia, it is noteworthy to analyze the characteristics of maternal mortality in order to describe the referral condition to the tertiary hospital in Indonesia. Therefore, this study aims to identify the determinants affecting maternal mortality, including individual and socio-demographic, maternal history, obstetric or reproductive history, and the mother's condition upon hospital admission.

\section{METHODS}

This was a descriptive study using cross sectional design which was held in RSCM to identify the characteristics of maternal deaths. The inclusion criteria were all maternal deaths occured in RSCM from January 2013 to December 2014. The exclusion criteria were if we did not find the medical records. This study had been approved by the Research Ethics Committee of the Faculty of Medicine, Universitas Indonesia through a Certificate of Conduct number 441/UN2.F1/ETIK/2015.

\section{RESULTS}

During the study period, we found 51 maternal deaths. Of them, $58.8 \%$ (30 subjects) were in the age group of 25-34 years old and the majority of educational background was graduated from high school (36 subjects; 70.6\%). A total of 90.2\% (46 subjects) finished nine-year education. There were 2 subjects aged less than 21 years old, namely 19 and 18 years old and both of them were primigravida. Meanwhile, there was one 41-year-old patient on her third pregnancy. All of these outliers experienced severe preeclampsia. Almost all subjects (50 subjects; $98.1 \%$ ) were housewifes. Actually, all subjects in this study used governmental insurance (Jampersal, JKN, BPJS) as financial resource.
Twenty-three subjects from multiparity and grandemultiparity had ever used contraception, whereas 7 subjects $(30.4 \%), 15$ subjects $(65.3 \%)$, 1 subject ( $4.3 \%)$ used pill, injection, condom; respectively. Only one subject with grandemultipara in fifth pregnancy never used any contraceptive methods.

Four subjects $(28.57 \%)$ delivered assisted by forceps; while, another one else (7.14\%) assisted by vacuum extraction. All patients with forceps extraction were caused by uncontrolled blood pressure on severe preeclampsia. The reason of using vacuum extraction was due to dystocia on second stage of labor. All subjects who did not undergo labor (4 subjects) and came with severe preeclampsia were accompanied by multi organ failure at less than 26 weeks of gestational age.

A total of 15 subjects (29.4\%) had a history of previous illness. Consisting of two subjects (13.3\%) with history of treatment for lung tuberculosis, 3 subjects (20\%) with hypertension, 2 subjects $(13.3 \%)$ with blood disorders (thalassemia and chronic granulocytic leukemia/CGL), 2 subjects $(13.3 \%)$ with an autoimmune disease (SLE and autoimmune hemolytic anemia/AIHA), 1 subject (6.7\%) with hepatitis B, 1 subject (6.7\%) with asthma, and 1 subject (6.7\%) with obesity. Only 1 subject (6.7\%) was known to be infected with HIV. All of the subjects were multigravidas, which 5 of them used contraception, while, 10 subjects never used contraception.

The majority of subjects (41 subjects, $80.4 \%$ ) had antenatal care done by midwifes. Fourteen subjects $(27.5 \%)$ had antenatal visits less than 4 times and 4 subjects $(7.8 \%)$ had never undergo antenatal care. Of 47 subjects who underwent ANC, only 14 subjects $(29.8 \%)$ who had undergone the ANC in the first trimester.

Table 1. The Characteristics of Subjects

\begin{tabular}{lcc}
\hline Characteristics & N & \% \\
\hline $\begin{array}{l}\text { Contraception } \\
\text { Yes }\end{array}$ & 23 & 45.1 \\
No & 28 & 54.9 \\
Parity & & \\
Primi & 18 & 35.3 \\
Multi & 32 & 62.8 \\
Grandemulti & 1 & 19
\end{tabular}




\begin{tabular}{lcc}
$\begin{array}{l}\text { Previous illnes } \\
\text { Yes }\end{array}$ & 15 & 29.4 \\
$\quad$ No & 36 & 70.6 \\
$\begin{array}{l}\text { Delivery method } \\
\quad \text { Vaginal delivery (Spontaneous/ }\end{array}$ & 14 & 27.5 \\
$\quad$ instrumental) & & \\
$\quad$ Caesarean section & 33 & 64.7 \\
$\quad$ Not delivered & 4 & 7.8 \\
Antenatal care (ANC) & & \\
$\quad$ Never & 4 & 7.8 \\
$\quad$ Midwife & 41 & 80.4 \\
$\quad$ Doctor & 6 & 11.8 \\
ANC frequency & & \\
$\quad$ Never & 4 & 7.8 \\
$\quad$ < 4 times & 14 & 27.5 \\
$\quad$ 4 times & 33 & 64.7 \\
\hline \hline
\end{tabular}

Fourteen subjects $(27.5 \%)$ came up with co-morbidities. The co-morbidities of subjects consisted of 10 (19.6\%), 12 (23.5\%), 8, 2, 1, and 1 subjects having eclampsia, postpartum hemorrhage, uterine atony, placental abruption, placenta previa, and uterine perforation; consecutively. Actually, the postpartum hemorrhage occurred outside RSCM in eight subjects and inside RSCM in 4 subjects were entirely caused by uterine atony. Of the 8 subjects who were referred to RSCM for bleeding, one subject was in third grade of shock, with less than 7 for hemoglobin level. She was applied an intravenous line without urine catether.

One subject in stage II dystocia was primigravidae, referred by midwifes, was in the second stage of labor for 3 hours. Finally, she was delivered by vacuum extraction and after delivering, she got postpartum hemorrhage due to uterine atony and birth canal laceration.

Of all patients who were referred or come with severe preeclampsia or eclampsia, there were 4 subjects without applying the intravenous line because they came without reference letter from secondary health centers. All preeclamptic patients had been given MgSO4 to avoid the convulsion and nifedipine for the blood pressure since at primary health. The majority of subjects (47 subjects, $92.2 \%$ ) were referral cases from other medical facilities. About 18 subjects (35.3\%) were referred in anemic condition.
Table 2. The Characeristics of Patient's Clinical Condition at Arrival

\begin{tabular}{lcc}
\hline \hline Variables & N & \% \\
\hline Comorbid Disease & & \\
$\quad$ Yes & 14 & 27.5 \\
$\quad$ No & 37 & 72.5 \\
Eclampsia & & \\
$\quad$ Yes & 10 & 19.6 \\
$\quad$ No & 41 & 80.4 \\
Dystocia & & \\
$\quad$ Yes & 1 & 1.9 \\
$\quad$ No & 50 & 98.1 \\
Ante/post partum bleeding & & \\
$\quad$ Yes & 12 & 23.5 \\
$\quad$ No & 39 & 76.5 \\
Hemoglobin & & \\
$\quad<10,5$ gr/dl & 18 & 35.3 \\
$\quad \geq 10,5$ gr/dl & 32 & 62.8 \\
No data & 1 & 1.9 \\
Referral status & & \\
Referred & 47 & 92.2 \\
By own will & 4 & 7.8 \\
\hline \hline
\end{tabular}

There were 14 subjects (27.5\%) in co-morbidity pregnancy. Meanwhile, six subjects $(15 \%)$ had cardiac abnormalities during pregnancy consisting of 2 subjects with atrial septal defect, 3 subjects with valvular heart disease, and 1 subject with aortic aneurysm. The other underlying diseases were such as one subject with HIV, one subject with pulmonary tuberculosis, one subject with pulmonary tuberculosis on going therapy, one subject with systemic lupus eritematosus, and another one with autoimmune hemolytic anemia. While, there were 2 subjects in blood disorder, namely chronic granulocytic leukemia and thalassemia for each patient.

Preeclampsia as a direct result of pregnancy abnormality was found in 26 subjects, whereas 10 of them suffered from eclampsia. All the patients with preeclampsia or eclampsia was on going of HELLP Syndrome at arrival.

Around 36 subjects (70.6\%) went through septic shock as the cause of death. Sepsis was the most common in the group of subjects with severe preeclampsia or eclampsia. Meanwhile, postpartum hemorrhage as the cause of death was happened in 8 subjects (15.7\%) (shown in Table $3)$. 
Table 3. Cause of Death

\begin{tabular}{lcc}
\hline \hline Cause of death & N & \% \\
\hline Sepsis & 36 & 70.6 \\
Hemorrhagic shock & 8 & 15.7 \\
CNS disorder & 5 & 9.8 \\
Cardiac abnormality & 2 & 3.9 \\
\hline \hline
\end{tabular}

\section{DISCUSSION}

Acknowledging the characteristics of maternal mortality and clinical spectrum in tertiary hospital makes the inspiration for the further research to prevent the maternal mortality. Campbell, et al. through their study stated that optimal intrapartum care was the best strategy to decrease the MMR. ${ }^{7,8}$ From these findings, it was possible to change the prevention strategy as most of deaths were due to preeclampsia/eclampsia. ${ }^{9}$ Meanwhile, there was a tendency that the majority of deaths were occurred in women doing the regular antenatal care at midwifes without risk factors analysis recorded. Therefore, we should improve the quality of antenatal care at midwifes. This can be achieved through regular training and education about screening and suggesting the midwifes to refer the women with high risk pregnancy.

\section{CONCLUSION}

The characteristics of maternal death in RSCM are prevalent in the group of 25-34 years old with the high school as the educational background. Most of them are multiparity and do not use the long-term contraceptive methods. Preeclampsia is the major cause of maternal death in RSCM.

\section{RECOMMENDATION}

Further study on early detection and prompt treatment of preeclampsia or eclampsia in primary care facilities should be conducted because pregnancy-induced hypertension is the most common causes of maternal mortality in this study. Improving antenatal care quality in primary center by providing continuing professional education for health workers there. Apart from that, the identification of preeclampsia should remain a priority in the clinical setting considering the contribution of these disease in MMR. The antenatal care utilization depends not only on number of visits, but also the health professional should be able to detect any problem rising during pregnancy and making the right referral. Finally, the ability to space and limit the pregnancy, especially in high risk group becomes the key point to reduce the MMR.

\section{REFERENCES}

1. WHO. International Classification of Diseases and Related Health Problems. Geneva: World Health Organization; 1992.

2. WHO. The WHO Application of ICD-10 to deaths during pregnancy, childbirth and the puerperium. ICD-MM; 2012.

3. AT DS. Penyebab kematian maternal di Indonesia, survey kesehatan rumah tangga 2001. Maj Ked Atmajaya. 2003.

4. Kemenkes. Profil Kesehatan Indonesia 2012. Jakarta: Kementerian Kesehatan RI; 2012.

5. Profil Kesehatan Provinsi DKI Jakarta Tahun 2012 Jakarta: Kementerian Kesehatan RI 2012 [cited 2015]. Available from: http://www.depkes.go.id/resources/download/ profil/PROFIL_KES_PROVINSI_2012/11 Profil_Kes.Prov.DKI Jakarta_2012.pdf.

6. RSUPN Dr. Cipto Mangunkusumo 2015. Available from: http://www.rscm.co.id.

7. Campbell OM, Graham WJ. Strategies for reducing maternal mortality: getting on with what works. Lancet. 2006; 368 (9543): 1284-99.

8. Moodley J. Maternal deaths due to hypertensive disorders in pregnancy. Best Practice and Research Clinical Obstet Gynecol. 2008; 22(3): 559-67.

9. WHO. WHO recommendations for prevention and treatment of pre-eclampsia and eclampsia: evidence base. Geneva: WHO Press; 2011. 